\title{
Controlled expression of recombinant proteins in Physcomitrella patens by a conditional heat-shock promoter: a tool for plant research and biotechnology
}

\author{
Younousse Saidi, Andrija Finka, Mickhail Chakhporanian, Jean-Pierre Zrÿd, Didier \\ G. Schaefer and Pierre Goloubinoff* \\ Department of Plant Molecular Biology, Lausanne University, Lausanne, CH-1015, Switzerland (*author for \\ correspondence; e-mail Pierre.Goloubinoff@unil.ch)
}

Received 30 May 2005; accepted in revised form 11 July 2005

Key words: acetyl salicylic acid, actin cytoskeleton, benzyl alcohol, GFP-talin, $\beta$-glucuronidase, Gmhsp17.3B promoter, inducible gene-expression system

\begin{abstract}
The ability to express tightly controlled amounts of endogenous and recombinant proteins in plant cells is an essential tool for research and biotechnology. Here, the inducibility of the soybean heat-shock Gmhsp 17.3B promoter was addressed in the moss Physcomitrella patens, using $\beta$-glucuronidase (GUS) and an F-actin marker (GFP-talin) as reporter proteins. In stably transformed moss lines, Gmhsp 17.3B-driven GUS expression was extremely low at $25^{\circ} \mathrm{C}$. In contrast, a short non-damaging heat-treatment at $38^{\circ} \mathrm{C}$ rapidly induced reporter expression over three orders of magnitude, enabling GUS accumulation and the labelling of F-actin cytoskeleton in all cell types and tissues. Induction levels were tightly proportional to the temperature and duration of the heat treatment, allowing fine-tuning of protein expression. Repeated heating/cooling cycles led to the massive GUS accumulation, up to $2.3 \%$ of the total soluble proteins. The anti-inflammatory drug acetyl salicylic acid (ASA) and the membrane-fluidiser benzyl alcohol (BA) also induced GUS expression at $25^{\circ} \mathrm{C}$, allowing the production of recombinant proteins without heat-treatment. The Gmhsp 17.3B promoter thus provides a reliable versatile conditional promoter for the controlled expression of recombinant proteins in the moss $P$. patens.

Abbreviations: ASA, acetyl salicylic acid; BA, benzyl alcohol; GFP, green fluorescent protein; GT, GFPtalin; GUS, $\beta$-glucuronidase; Fv/Fm, the maximal photochemical efficiency of PSII; MU, 4-methylumbelliferone; MUG, 4-methylumbelliferyl- $\beta$-D-glucuronide; PSII, photosystem II; SA, specific activity; sHSP, small heat-shock protein; TSP, total soluble proteins; Ubi, ubiquitin; X-Gluc, 5-bromo-4-chloro-3indolyl- $\beta$-D-glucuronide
\end{abstract}

\section{Introduction}

The use of inducible protein-expression systems in model multi-cellular organisms is central to research in molecular genetics. The ability to induce and regulate the expression of recombinant proteins at will, is a valuable tool to correlate protein levels with biological functions, to localize proteins in the cell and to visualize protein dynamics in vivo at various stages of development. This approach is exemplified by the wide use of conditional promoters such as lacZ in Escherichia coli (Donovan et al., 1996), GAL4 in budding yeast (Johnston, 1987) and nmt 1 in 
fission yeast (Maundrell, 1993). Efficient high protein expression is also central to the production of recombinant proteins for biotechnology and pharmaceutics.

Ideal inducible gene-expression systems should meet the following requirements: (1) without induction, expression should be the least leaky possible. (2) Induction should be dose-dependent and induction levels should span over at least three orders of magnitude. (3) The pattern of protein expression should be homogenous in all tissue of the organism and (4) inducing conditions should bare minimal consequences on the organism's physiology, fitness and viability (Gatz, 1997). In plants, prevalent conditional geneexpression systems use chemically regulated heterologous promoters (reviewed in (Padidam, 2003)) with chemical inducers such as tetracycline (Gatz, 1997), steroids (Aoyama and Chua, 1997; Zuo et al., 2000) and ethanol (Caddick et al., 1998; Roslan et al., 2001). These systems may reach up to a few hundred folds of induction, but there are major limitations such as promoter leakiness, non-uniform uptake and toxic effects of the inducing chemicals (reviewed in details in (Padidam, 2003)).

Plants are sessile organisms with outstanding abilities to withstand temperature stresses. Gene expression in plants can therefore be induced by a mild heat-shock with minor impact on the fitness, using expression cassettes driven by heat-regulated promoters (Ainley and Key, 1990; Schöffl et al., 1989). Plant heat-inducible promoters are well known for their strong, rapid and short lasting transcriptional response to heat stress (Vierling and Kimpel, 1992; Nover et al., 2001). The plant promoters from the small heat shock protein (sHSP) gene family provide highly sensitive responses to mild temperature variations (Sun et al., 2002). Thus, in Nicotiana tabacum the promoter hsp17.6L from soybean can control antibiotic resistance in a temperature-dependent manner (Severin and Schoffl, 1990) as well as the expression of the FLP recombinase in maize (Lyznik et al., 1995) and Arabidopsis thaliana (Kilby et al., 2000). Similarly, the A. thaliana hsp 18.2 promoter was successfully used as a heat-inducible expression system in tobacco BY2 cells (Yoshida et al., 1995), and to achieve heat-inducible RNAi expression in $A$. thaliana (Masclaux et al.,
2004). Recently, using the soybean Gmhsp $17.3 B$ promoter, inducible insertional mutagenesis, based on $A c-D s$ transposons, was developed in A. thaliana (Nishal et al., 2005).

The moss Physcomitrella patens is emerging as a powerful model system for plant functional genomics. It shares many biological features with other land plants, in terms of gene conservation, physiology and development (Reski, 1998). At the same time $P$. patens offers the unique opportunity to perform targeted mutagenesis in a complex multi-cellular land plant by efficient homologous recombination (Schaefer and Zryd, 1997; Schaefer, 2002). Moreover, genetic studies in haploid mosses such as $P$. patens are much simpler than in diploid plants (Cove et al., 1997; Schaefer and Zryd, 2001). Molecular tools (Schaefer and Zryd, 2004) and genetic information (Rensing et al., 2002; Nishiyama et al., 2003) are rapidly developing for P. patens. However, one tool still in need to be developed is a versatile conditional gene-expression system allowing to generate conditional phenotypes and circumvent lethality in mutations of essential genes. A tetracyclinerepressible gene-expression system has been reported in P. patens (Zeidler et al., 1996), but it requires continuous growth on tetracycline, which is detrimental to the moss (Laloue M., personal communication). Abscissic acid or auxin-induced gene expression have also been shown using, respectively, the wheat $E m$ gene promoter (Knight et al., 1995) or the soybean GH3 gene promoter (Bierfreund et al., 2003). However, the use of phyto-hormone-regulated gene expression may interfere with the plant physiology and remain unfit for a general versatile conditional gene-expression system in plants.

Here, we describe a highly efficient inducible protein-expression system in the moss $P$. patens, using the $h s p 17.3 B$ promoter of a soybean class I sHSP (Gmhsp17.3B gene, SwissProt P02519, EMBL X011041 (Schöffl et al., 1984)). Heatinduced expression of a soluble reporter enzyme (GUS) and of a cytoskeletal marker (GFP-talin) was characterized. A short heat-treatment under non-damaging conditions rapidly induced dosedependent protein accumulation, in the whole plant. At $25^{\circ} \mathrm{C}$, protein expression remained tightly repressed, unless plants were exposed to specific chemical inducers, such as benzyl alcohol (BA) or acetyl salicylic acid (ASA). 


\section{Materials and methods}

\section{Plasmids}

pHSP-GUS-AH108 and pHSP-GT-AH108

Plasmid pHsp-2 contains the promoter region ( -512 to $-5 \mathrm{bp}$ ) from the soybean $h s p 17.3 B$ gene (Schöffl et al., 1984) cloned as an XbaI-BamHI fragment in pBSKS II (kind gift from Eric Lam, Rutgers University). pHSP-GUS contains the BamHI/KpnI GUS-CaMVter fragment from pNco-GUS (Bonneville et al., 1989) cloned into the corresponding sites of pHsp-2. pHSP-GT was constructed by replacing the NcoI - EcoRI GUS-CaMVter fragment of pHSP-GUS with a NcoI - EcoRI GFP-talin-CaMVter fragment from pYSC14 (Kost et al., 1998). Finally, a $4.7 \mathrm{~kb}$ KpnI fragment from pBS-BAMH108 vector (A. Finka, unpublished) containing a hygromycin resistance cassette driven by the rice actin-1 gene promoter (McElroy et al., 1991) and a $1.9 \mathrm{~kb}$ of PP-108 genomic locus as targeting fragment (Schaefer and Zryd, 1997), was inserted in the KpnI restriction site of both vectors to create the pHSP-GUS-AH108 and pHSP-GTAH108 targeting vectors used in moss transformation.

pUBI-GUS-MU108H pUbi-GUS (Schweizer et al., 1999) was digested by HindIII, to release a $4.2 \mathrm{~Kb}$ fragment containing ubiquitin-1 promoter from maize, the uidA gene and $35 \mathrm{~S}$ terminator. This fragment was cloned in the HindIII digested $\mathrm{pMU} 108 \mathrm{H}_{2}$ transformation vector (M. Uzé, unpublished) carrying the PP-108 genomic locus (Schaefer and Zryd, 1997) and a hygromycin resistance cassette driven by $35 \mathrm{~S}$ promoter (Details provided upon request).

\section{Plant material and protoplast transformation}

Physcomitrella patens was grown on agar containing minimal medium (Ashton et al., 1979) overlaid with a cellophane disk, as previously described (Schaefer and Zryd, 1997). Isolation of protoplasts, polyethylene glycol-mediated transformation, regeneration and selection of hygromycin-resistant transgenic moss strains was performed as described earlier (Schaefer and Zryd, 1997). Protoplasts were transformed with circular pHSP-GUS-AH108, pHSP-GT-AH108 and pUBI-GUS-MU108 $\mathrm{H}_{2}, \quad$ generating HSP::GUS, HSP::GT and UBI::GUS lines, respectively.

\section{Heat treatment}

Six days old $P$. patens protonemata or 8 weeks old gametophores were transferred to liquid minimal medium and liquid-adapted at $25^{\circ} \mathrm{C}$ for $1 \mathrm{~h}$. Heat treatment was then performed in a temperature-controlled water bath at the indicated temperatures and durations. Unless indicated otherwise, heat-treated mosses were tested for GUS activity or fixed for histochemical staining after $16 \mathrm{~h}$ recovery at $25^{\circ} \mathrm{C}$. For HSP::GT lines, heat treatments were performed by transferring moss tissue on preheated agar plates containing minimal medium and incubated in temperature-controlled chamber. We did not observe differences between heat treatments on solid and in liquid media.

\section{Chemical treatments}

For BA treatment, 6 days old $P$. patens protonemata were transferred $1-\mathrm{h}$ prior treatment to liquid medium to which was added BA (Fluka), or ethanol (Fluka) to the indicated final concentrations. Following $1 \mathrm{~h}$ treatment at $25^{\circ} \mathrm{C}$, mosses were washed 3 times with minimal medium and incubated without inducer at $25^{\circ} \mathrm{C}$ for $16 \mathrm{~h}$, then tested for GUS activity.

For ASA treatment, protonemata were transferred to a solid medium supplemented with O-Acetyl salicylic acid (ASA) (Fluka) at the indicated concentrations. ASA was added from a (1 M) stock solution in dimethylsulphoxide (DMSO) to the sterilized medium. DMSO was added at equivalent concentrations as control. Plates were then placed in the growth chamber at $25^{\circ} \mathrm{C}$ for $1 \mathrm{~h}$. After ASA treatment, mosses were returned to the original ASA-less medium and, after $16 \mathrm{~h}$ recovery at $25^{\circ} \mathrm{C}$, tested for GUS activity or GFP-talin labelling. No significant change in the $\mathrm{pH}$ of the medium was detected in the presence of the highest ASA concentration.

\section{GUS assay}

GUS activity was determined according to (Jefferson et al., 1987), using 2 mM 4-methylum- 
belliferyl- $\beta$-D-glucuronide (MUG) as substrate in $110 \mu \mathrm{l}$ final reaction volume. Production of 4-methylumbelliferone (MU) was monitored kinetically on a microtiter plate Fluoroscan reader, using fresh serial dilutions of MU as standards (excitation wave length $365 \mathrm{~nm}$ and emission wave length $450 \mathrm{~nm}$ ). Protein concentrations in the extracts were determined by the Bradford method (BioRad). GUS specific activity (SA) were expressed as nmol MU produced per minute per mg protein. Extracts with high GUS specific activities were diluted ten folds in extraction buffer with $1 \mathrm{~g} / 1 \mathrm{BSA}$, to stay in the linear measuring rate of the Fluoroscan.

Histochemical assays were as in (Nishiyama et al., 2000) with small modifications. Plant tissues were fixed in a solution containing $0.3 \%(\mathrm{v} / \mathrm{v})$ formalin, $5.45 \%(\mathrm{w} / \mathrm{v})$ mannitol and $0.2 \%(\mathrm{w} / \mathrm{v})$ MES-KOH (pH 5.6) during $30 \mathrm{~min}$ at room temperature, washed 3 times with $50 \mathrm{mM} \mathrm{NaH}$ $\mathrm{PO}_{4}(\mathrm{pH}$ 7.0). After a brief vacuum infiltration, tissues were incubated at $37^{\circ} \mathrm{C}$ in a $500 \mu \mathrm{X}$-gluc solution (1 mM 5-bromo-4-chloro-3-indolyl- $\beta$ D-glucuronide (Duchefa Biochemie B.V. Netherlands), $50 \mathrm{mM} \mathrm{NaH} \mathrm{PO}_{4}$ (pH 7.0), $0.05 \%$ Triton $\mathrm{X}-100$ ), and coloration was followed in time. Tissues were fixed $10 \mathrm{~min}$ in $5 \%$ formalin, and $10 \mathrm{~min}$ in $5 \%$ acetic acid. Tissue pigments were removed by serial ethanol incubation $(30 \%, 50 \%$, $70 \%$ and $95 \%$ ). The stained tissues were observed under a light microscope and images were acquired using a LEICA DC 200 camera.

To correlate specific GUS activity with known amounts of GUS protein, the GUS enzyme was purified to at least $95 \%$ from heat-induced total moss protein extracts, by ion exchange chromatography (on ResourseQ, Pharmacia), using a linear gradient of $50-500 \mathrm{mM}$ $\mathrm{KCl}$. The GUS activity of the purified fraction was correlated on SDS-PAGE with a standard curve of Coomassie blue-stained GUS bands and of a known amount of the G6PDH enzyme (Diamant et al., 2000).

\section{Western blotting}

Twenty microgram of moss crude soluble protein extracts were fractioned on $10 \%$ SDS-PAGE. Proteins were transferred to a nitrocellulose membrane (Bio-Rad) by electroblotting and incubated with a rabbit-derived polyclonal antibody (Molec- ular probes) against GUS and diluted 1/500 (v/v). The blot was then incubated with HRP-conjugated anti-rabbit IgG (Promega) diluted 1/2500 (v/v). Immune complexes were visualized using the chemiluminescent Immunstar ${ }^{\mathrm{TM}}$ Kit (Bio-Rad) according to manufacturer's instructions.

\section{Measurement of PSII activity}

Chlorophyll a fluorescence measurements were made with the Plant Efficiency Analyser PEA ${ }^{\circledR}$ from Hansatech Instruments Ltd, UK as detailed by (Strasser et al., 1995). To measure chlorophyll $a$ florescence, a small sample of moss protonema was placed on the cellophane disk and surrounded by the $5 \mathrm{~mm}$ diameter plastic clip provided by the instrument. Measurements were taken following a brief (2s) strong illumination of protonemata that have been previously dark-adapted for $2 \mathrm{~min}$. Illumination red light of $3000 \mu \mathrm{mol} \mathrm{m}^{-2} \mathrm{~s}^{-1}$ (peak at $650 \mathrm{~nm}$ ) was provided by the PEA sensor unit. The following parameters were assessed: $F_{0}, F_{m}$ and $\mathrm{F}_{\mathrm{v}}$ (Strasser et al., 1995). The $\mathrm{Fv} / \mathrm{Fm}$ ratio is the maximal photochemical efficiency of Photosystem II (PSII), with $F_{v}=F_{m}-F_{0}$ where $F_{0}$ and $F_{m}$ are respectively, minimum and maximum florescence of dark-adapted protonema.

\section{Live cell microscopy and image analysis}

For confocal microscopy, excised pieces of cellophane carrying undamaged moss tissue were transferred into the glass slide chamber (Lab Tek II, Nunc) in inverted position and covered with a block of solid medium. Confocal microscopy was performed on a LEICA TCS SP2 system, using an inverted microscope (LeicaDMRE). A krypton-argon laser (488 nm line) was used for excitation. The bandwidth mirror settings for discriminating between the GFP fluorescence and red auto-fluorescence of chloroplasts were 504/531 for GFP and 634/696 for TRITC (chloroplasts). The two channels were allocated false green (GFP) and red (TRITC) colours. The step size between image slices was $0.65 \mu \mathrm{m}$. The obtained images represent orthogonal projections of 150 slices in the image stack. These projections were processed using Photoshop 6.0 software (Adobe Systems, Mountain View, CA). 


\section{Results}

Generation of transgenic HSP::GUS, HSP::GT and UBI::GUS moss lines

In this study, we used three transformation vectors, all carrying a selectable hygromycin resistance gene, $2 \mathrm{~Kb}$ of the genomic PP-108 locus as targeting sequence (Schaefer and Zryd, 1997) and the reporter expression cassettes HSP::GUS, HSP::GT (GFP-talin) or UBI::GUS (see Materials and methods). Targeted integration of the tested cassettes in the PP-108 locus of the moss chromosome considerably reduces the variability between different transgenic lines and allows a precise comparison between the activities of different reporter genes integrated at the same chromosomal location. Following direct transformation of $P$. patens protoplasts, stable hygromycin-resistant plants were regenerated: six lines with HSP::GUS, thirteen with HSP::GT and four with UBI::GUS. Southern blot analysis confirmed the stable integration of 5-10 direct repeats of the transforming plasmids in the PP-108 locus (data not shown).

At $25^{\circ} \mathrm{C}$, a very weak GUS activity was detected in HSP::GUS lines (specific activity (SA) of $0.59 \pm 0.17 \mathrm{nmol} \mathrm{MU} / \mathrm{min} \mathrm{mg}$ averaged from six different lines). Expectedly, in the UBI::GUS lines, the GUS activity was over 100-fold higher (SA $73.3 \pm 14 \mathrm{nmol} \mathrm{MU} / \mathrm{min} \mathrm{mg}$ averaged from four different lines) than in HSP::GUS lines (Figure 1A). Unless otherwise stated, one representative of each stably transformed line was randomly chosen for further studies.

\section{In the HSP::GUS line, GUS is strongly induced by heat treatment}

One-week-old protonemata from the HSP::GUS and UBI::GUS lines were treated for $60 \mathrm{~min}$ at increasing temperatures. Following $16 \mathrm{~h}$ recovery at $25^{\circ} \mathrm{C}$, GUS activities were measured in crude extracts. In the HSP::GUS strain, the GUS activity displayed a remarkable temperaturedependent response (Figure 1A). Compared to $25^{\circ} \mathrm{C}, 1 \mathrm{~h}$ at $32{ }^{\circ} \mathrm{C}$ induced GUS expression 24-fold (SA $13.7 \pm 9.6 \mathrm{nmol} \mathrm{MU} / \mathrm{min} \mathrm{mg}$ ), at $34{ }^{\circ} \mathrm{C}$ more than 100 -fold (SA $66.8 \pm 31 \mathrm{nmol}$ $\mathrm{MU} / \mathrm{min} \mathrm{mg}$ ) and at $38^{\circ} \mathrm{C}$, up to 1500 -fold (SA $854 \pm 31 \mathrm{nmol} \mathrm{MU} / \mathrm{min} \mathrm{mg}$ ). Above $40{ }^{\circ} \mathrm{C}$, sub-maximal GUS activities were observed,

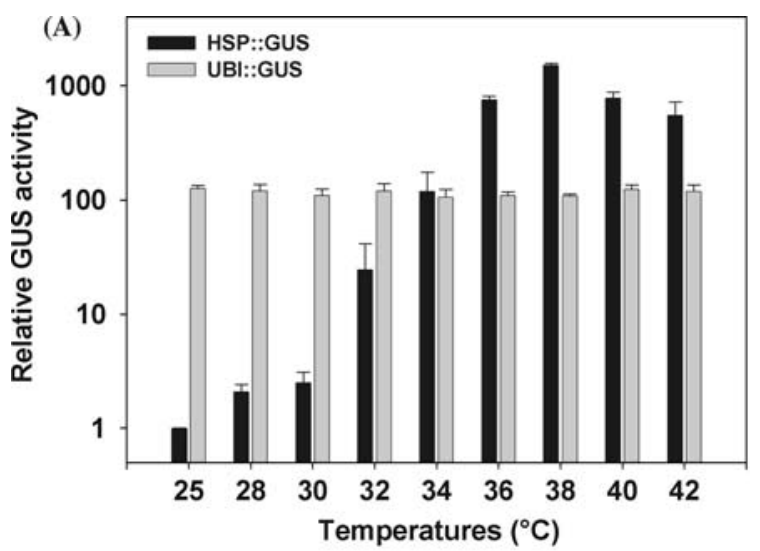

(B)
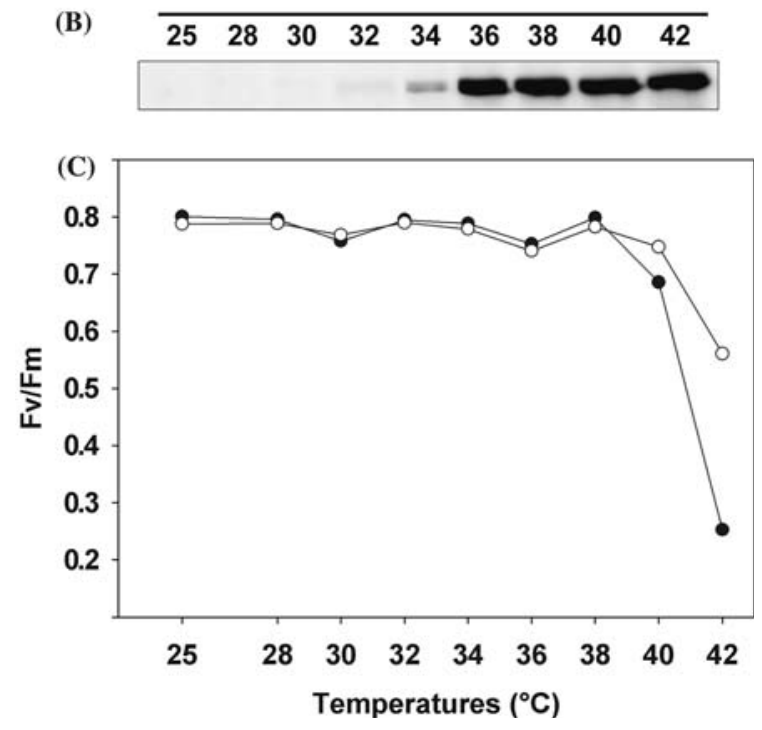

Figure 1. Heat-induction of the GUS enzyme. (A) GUS expression levels after heat treatment at different temperatures. P. patens protonemata from HSP::GUS (plain bars) and UBI::GUS (grey bars) lines were heat-treated for $1 \mathrm{~h}$ at indicated temperatures. GUS activities were measured after $16 \mathrm{~h}$ of recovery at $25^{\circ} \mathrm{C}$. After $1 \mathrm{~h}$ at $25^{\circ} \mathrm{C}$, GUS SA was $0.5 \pm 0.12$ and $62.7 \pm 4.47 \mathrm{nmol} \mathrm{MU} / \mathrm{min} \mathrm{mg}$ in HSP::GUS and UBI::GUS line respectively. After $1 \mathrm{~h}$ at $38^{\circ} \mathrm{C}$, GUS SA was $854.29 \pm 31 \mathrm{nmol} \mathrm{MU} / \mathrm{min} \mathrm{mg}$ in HSP::GUS line. GUS activities were determined from three independent experiments and were expressed relatively to the level of expression in HSP::GUS line at $25^{\circ} \mathrm{C}$, witch was arbitrary fixed to 1 . (B) Western blot analysis of GUS amounts as in a. Equal amounts of crude soluble protein extracts $(20 \mu \mathrm{g})$ were loaded and fractionated by $10 \%$ SDS-PAGE, blotted, and probed using an anti-GUS antibody. (C) Effect of increasing temperatures on the $\mathrm{Fv} / \mathrm{Fm}$ in $P$. patens. Chlorophyll a fluorescence of HSP::GUS protonema was measured immediately after $1 \mathrm{~h}$ heat treatment $(\bullet)$ and following $16 \mathrm{~h}$ of recovery at $25^{\circ} \mathrm{C}$ (O). 
suggesting some heat damages. The temperaturedependent pattern of GUS expression was confirmed by western-blot (Figure 1B). In contrast, the maize ubiquitin (Ubi-l) promoter was found to drive a constant, strong GUS expression, which remained unaffected by the various heattreatments (Figure 1A). This observation confirms that the Ubi-1 promoter is not responsive to heat-treatment and that $60 \mathrm{~min}$ exposure at $42{ }^{\circ} \mathrm{C}$ does not significantly affect the stability of the GUS enzyme already present in $P$. patens cells. Noticeably, GUS expression levels in the UBI::GUS line were at least 10-fold lower than the maximal GUS expression in heat-induced HSP::GUS. Five minutes heat-shock at $45^{\circ} \mathrm{C}$ is optimal for moss protoplast transformation (Schaefer and Zryd, 1997). We found that this strong but short heat-shock induced the same optimal high level of GUS expression as mild $60 \mathrm{~min}$ at $38{ }^{\circ} \mathrm{C}$ (data not shown).

The specificity of the heat-response in the HSP::GUS strain was demonstrated with other stresses: cold shock $\left(60 \mathrm{~min}\right.$ at $\left.4-15^{\circ} \mathrm{C}\right)$, salt (20 hours on $\mathrm{NaCl} 50-250 \mathrm{mM}$ at $25^{\circ} \mathrm{C}$ ) and osmotic stress ( $20 \mathrm{~h}$ on $0.48 \mathrm{M}$ mannitol at $25^{\circ} \mathrm{C}$ ) induced very low GUS expression, comparable to that observed at $25^{\circ} \mathrm{C}$ (data not shown).

\section{Optimal heat inducing treatments cause no apparent damages}

Photosynthetic activity is among the most sensitive functions of plant cells. PSII becomes readily damaged by various stresses (Krueger et al., 1997; Lu et al., 2003), in particular by heat-stress (Havaux, 1992; Srivastava et al., 1997). The maximal photochemical efficiency of PSII corresponding to $\mathrm{Fv} / \mathrm{Fm}$ was measured in moss tissues immediately and $16 \mathrm{~h}$ after the heat-treatment (see Materials and methods). As shown in Figure 1C, 60 min at up to $38{ }^{\circ} \mathrm{C}$ caused no measurable damage in the photochemical efficiency of PSII. However, exposure to $40{ }^{\circ} \mathrm{C}$ resulted in a $10 \%$ decrease of $\mathrm{Fv} /$ $\mathrm{Fm}$, which was fully restored during the $16 \mathrm{~h}$ recovery period. Expectedly, exposure to $42{ }^{\circ} \mathrm{C}$ caused more severe damage ( $70 \%$ decrease of $\mathrm{Fv} /$ $\mathrm{Fm}$ ), which was only partially restored during recovery (Figure 1C). These partial damages correlate with the sub-optimal GUS activities we measured following 1-h induction at 40 and $42{ }^{\circ} \mathrm{C}$. We conclude that optimal conditions for maximal protein induction $\left(1 \mathrm{~h}\right.$ at $\left.38{ }^{\circ} \mathrm{C}\right)$ have no significant deleterious effect on the moss physiology. Thus, an essential criterion of quality for a new inducible gene-expression system in $P$. patens is fulfilled.

\section{Induction levels can be tightly controlled by the duration of the heat-treatment}

Heat-induced expression of sHSP is one of the most sensitive, rapid and short lasting molecular responses in plants (Merquiol et al., 2002; Sun et al., 2002; Rizhsky et al., 2004). To determine when the heat-response becomes saturated and how accurate is the control of expression by the duration of the heat-treatment, we measured the GUS activity resulting from increasing periods of heat-exposure at $38^{\circ} \mathrm{C}$. Confirming the temperature independent nature of the Ubi-1 promoter, two hours exposure at $38{ }^{\circ} \mathrm{C}$ did not affect the constant high level of Ubi-1-expressed GUS (Figure 2A). By contrast, a tight, reproducible correlation was observed between the duration of heat-induction and the level of $h s p 17.3 B$-expressed

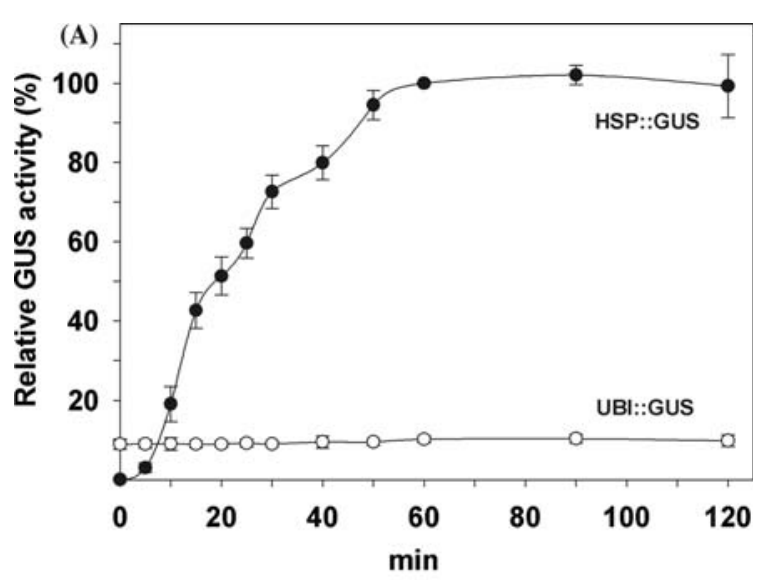

(B)

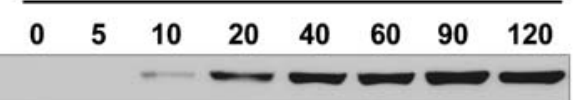

Figure 2. Time-dependent induction of GUS expression at $38^{\circ} \mathrm{C}$. (A) Time-dependent induction of GUS expression at $38^{\circ} \mathrm{C}$. Protonemata from HSP::GUS (-) and UBI::GUS (O) strains were heat treated for the indicated durations. GUS activities were measured $16 \mathrm{~h}$ after heat-treatment. $60 \mathrm{~min}$ at $38^{\circ} \mathrm{C}$, generated $860 \pm 85.29 \mathrm{nmol} \mathrm{MU} / \mathrm{min} \mathrm{mg}$ in HSP::GUS strain, normalised to $100 \%$ induction. Mean values were established from six independent experiments. (B) Western blot analysis of GUS accumulation, performed as in Figure 1. 
GUS (measured $16 \mathrm{~h}$ later). The half optimal induction time (at $38^{\circ} \mathrm{C}$ ) was $20 \mathrm{~min}$. Optimal induction time was $60 \mathrm{~min}$, producing over 1500fold more GUS activity than at $25^{\circ} \mathrm{C}$ (Figure 2A). Prolonged incubation beyond $60 \mathrm{~min}$ did not affect the high level of GUS activity. This gradual accumulation of GUS protein was confirmed by western blot analysis as shown in Figure 2B. The small standard errors, obtained with independent measurements using different HSP::GUS lines, demonstrate the tight reproducible control over this $h \operatorname{sp} 17.3 B$ promoter.

\section{The kinetics of heat-induced gene expression}

To further characterise the $h s p 17.3 B$ promoter in moss, we measured the kinetics of GUS expression at $25{ }^{\circ} \mathrm{C}$, following $1 \mathrm{~h}$ induction at $38^{\circ} \mathrm{C}$. Remarkably, $15 \%$ of the optimal GUS expression was already synthetised and active at the end of the heat-treatment (Figure 3A, inset, time 0). This confirms that both transcriptional and translational machineries are functional during the heatshock. During the subsequent incubation at $25{ }^{\circ} \mathrm{C}$, half maximal GUS expression was reached $4 \mathrm{~h}$ after heat-treatment and maximal GUS expression after $8-10 \mathrm{~h}$ (Figure 3A, inset). Maximal GUS levels remained stable during the $24 \mathrm{~h}$ post-induction and then gradually degraded at a rate of $10-15 \%$ per day (Figure 3). The GUS protein is highly stable in plant cells (Jefferson et al., 1987) and expectedly, 1 week following induction, a third of the maximal GUS amounts was still present in the plant cells. Immunoblot analysis showed the rapid GUS accumulation during and after heat-induction, followed by a much slower rate of degradation (Figure 3B).

The pattern of hsp17.3B-mediated protein expression is uniform

To define the pattern of $h s p 17.3 B$-driven gene expression in different tissues, and to test its suitability for in vivo labelling approaches in moss, we performed histochemical staining of protonemata and differentiated leafy shoots from the HSP::GUS line, and a microscopic analysis of the actin network in the HSP::GT tissues. As expected, no X-gluc staining was detected in protonemata or gametophores of the non-induced HSP::GUS line, even following $12 \mathrm{~h}$ incubation in revealing buffer
(Figure 4A, D). This confirms that without heattreatment, there is no detectable cell-specific expression of $h s p 17.3 B$-driven gene in the moss gametophyte. In contrast, a strong GUS staining was observed following heat-treatment in nearly all cells of HSP::GUS protonema and gametophore (Figure 4B, E). This histochemical staining was homogenous in all tissues. Noticeably, the pattern of Ubi-1-mediated expression was heterogenous. GUS staining in the UBI::GUS line was stronger in the older cells of the protonema and gametophore (Figure 4C, F). This is consistent with the constitutive nature of the Ubi- 1 promoter, allowing a progressive accumulation of the stable GUS enzyme in older cells.

The expression of green fluorescent protein (GFP) fused to other proteins is widely used as a tool to investigate the protein sub-cellular localization and to observe structural protein complexes in vivo. The GFP-talin fusion allows the nondestructive labelling of F-actin filaments in higher plants (Kost et al., 1998). Here we used the in vivo

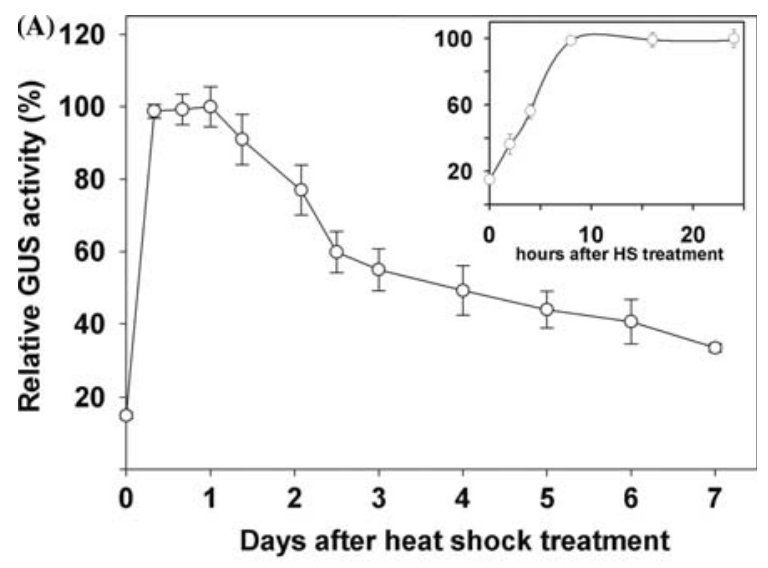

(B)

\begin{tabular}{|l|lllllllll}
\multicolumn{7}{c}{ hours after heat shock treatment } \\
\hline NI & 0 & 2 & 4 & 8 & 16 & 24 & 72 & 96 \\
\hline & & & & & & & & &
\end{tabular}

Figure 3. Time-dependent accumulation and degradation of GUS after induction. (A) One week old protonemata from the HSP::GUS strain were heat treated $1 \mathrm{~h}$ at $38{ }^{\circ} \mathrm{C}$ and subsequently grown at $25^{\circ} \mathrm{C}$. GUS activities were measured in samples collected at the indicated time up to 7 days after heat treatment. GUS activities were represented as percentage of the maximal expression level. Inset, GUS activity during the first $24 \mathrm{~h}$ following heat-treatment (HS). Mean values were established from 3 independent experiments. (B) Immunoblot analysis of GUS amounts as in a. NI: total proteins extracted before heat treatment. 0 : total proteins extracted immediately after heat treatment. 


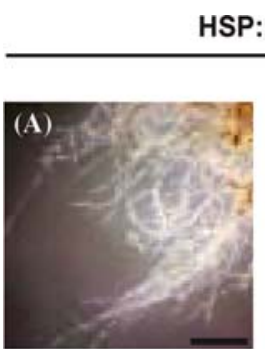

(D)

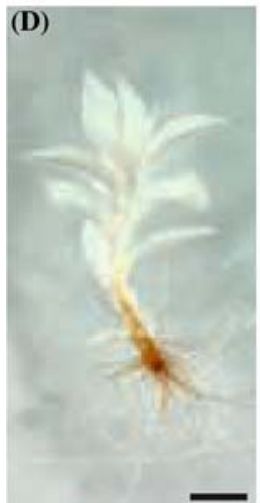

HSP::GUS

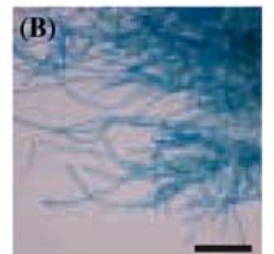

(E)

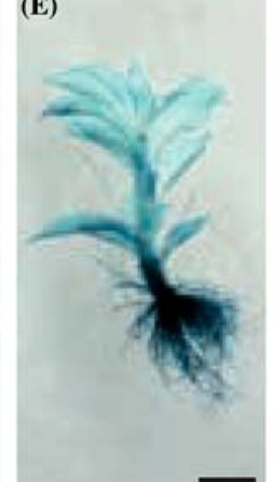

UBI::GUS

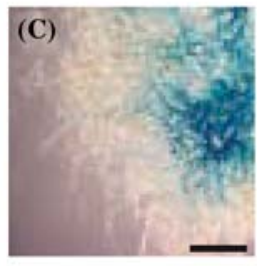

(F)

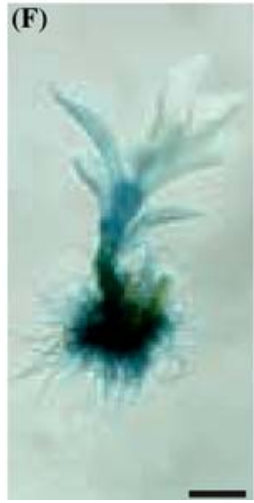

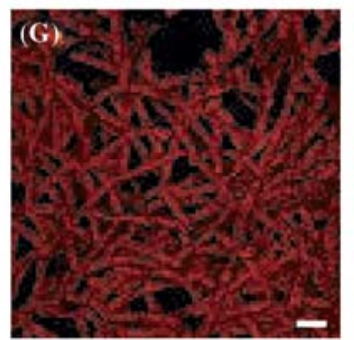

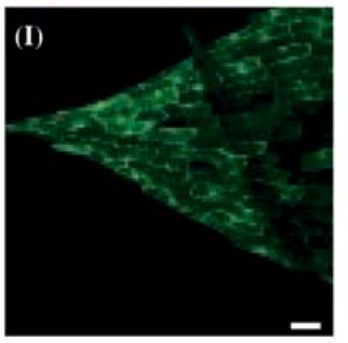

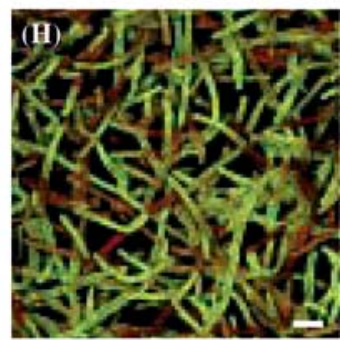

HSP::GT

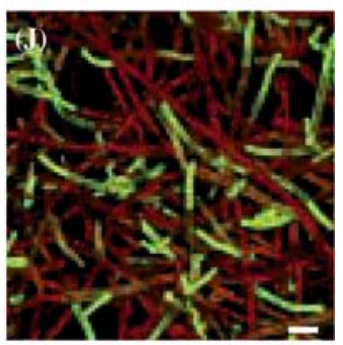

Figure 4. Expression pattern of the $h s p 17.3 B$ and the ubiquitin promoter. (A-F) Histochemical localization of GUS expression driven by the $h \operatorname{sp} 17.3 B$ (A, B, D and E) or the Ubi-1 (C and F) promoter. Protonema from non-induced HSP::GUS (A), heat-treated $\left(1 \mathrm{~h}, 38^{\circ} \mathrm{C}\right)$ HSP::GUS (B), and untreated UBI::GUS (C) strains. Gametophores from non-induced HSP::GUS (D), heat-treated HSP::GUS (E) and untreated UBI::GUS (F) strains. The staining pattern in UBI::GUS was identical with or without heat treatment (data not shown). Tissues were incubated $12 \mathrm{~h}(\mathrm{~A}, \mathrm{D}), 1 \mathrm{~h}(\mathrm{~B}, \mathrm{C})$ and $4 \mathrm{~h}(\mathrm{E}, \mathrm{F})$ in X-gluc solution at $37^{\circ} \mathrm{C}$. Bars: $500 \mu \mathrm{m}$. G-J: Confocal projections of HSP::GT protonema and leaf tissue. (G) Untreated protonema displaying chlorophyll autofluorescence but no GFP fluorescence, $(\mathrm{H})$ heat-treated $\left(1 \mathrm{~h}, 38^{\circ} \mathrm{C}\right)$ protonema displaying chlorophyll autofluorescence and strong GFP in every cell, (I) GFP labelled actin structures in an induced leaf, (J) protonema treated with ASA displaying GFP labelling in young cells. Bars: $100 \mu \mathrm{m}$.

labelling of the $P$. patens actin network with the GFP-talin marker (GT) to evaluate the potential of the $h \mathrm{sp} 17.3 \mathrm{~B}$ promoter to monitor the dynamics of protein complexes in moss. As with HSP::GUS line, GFP decorated actin structures were not observed in non-treated HSP::GT plants (Figure 4G). Dose-response experiments showed that optimal conditions for heat induction of GT were similar to those described for HSP::GUS lines, i.e. one hour at $38{ }^{\circ} \mathrm{C}$, for optimal labelling observed $16 \mathrm{~h}$ later (data not shown). In heat-treated plants, all protonema and gametophore cells displayed clear GFP-labelled actin structures (Figure 4H, I). Cortical actin cables, a fine meshwork of actin around the nucleus and the accumulation of actin at active growth sites were clearly detectable (A. Finka, manuscript in preparation). Similar actin structures have been described in $P$. patens cells following histochemical staining with rhodamin-phalloidin (Doonan and Duckett, 1988).
Over-production of recombinant proteins by 'in physco' thermocycling

Induction being exhausted beyond one hour at $38^{\circ} \mathrm{C}$, we addressed the possibility to increase the yields of expressed GUS protein by iterative thermocycling treatment of the moss. HSP::GUS protonemata were submitted to three consecutive cycles of $1 \mathrm{~h}$ at $38{ }^{\circ} \mathrm{C}$ and $4 \mathrm{~h}$ at $25^{\circ} \mathrm{C}$. After one, two and three such 'in physco' thermocycles, GUS accumulated respectively to $1 \%$ (SA $697.3 \mathrm{nmol}$ $\mathrm{MU} / \mathrm{min} \mathrm{mg}$ ), $1.7 \%$ (SA $1264 \mathrm{nmol} \mathrm{MU} / \mathrm{min}$ $\mathrm{mg}$ ) and $2.3 \%$ (SA $1709 \mathrm{nmol} \mathrm{MU} / \mathrm{min} \mathrm{mg}$ ) of the total soluble proteins (TSP). This suggests that after the first heat-shock, a short incubation at $25{ }^{\circ} \mathrm{C}$, during which partial GUS synthesis is achieved, can reset the heat-shock induction machinery and initiate synthesis of additional mRNA and GUS protein during in the next cycles. These high amounts was readily detectable by 
coomassie blue staining on SDS-polyacrylamide gel (Figure 5, line 1, 2,3). As expected, no GUS was detected in extracts of heat-treated wild type (WT) and untreated HSP::GUS line (NI) (Figure 5). The maximal yield obtained here corresponds to $3.5 \mathrm{mg}$ GUS protein per gram dry weight.

\section{Chemical induction of the hsp17.3B promoter in $\mathrm{P}$. patens}

At non-inducing temperatures, the heat-shock response can be induced in bacteria and animal cells by specific chemicals affecting membrane fluidity (Vigh et al., 1998) and/or protein stability (Jurivich et al., 1992). The membrane fluidiser benzyl alcohol BA can optimally induce the heatshock response in E. coli and cyanobacteria (Shigapova et al., 2005; Vigh et al., 1998). We found here that the $h s p 17.3 B$ promoter was proportionally induced by $1 \mathrm{~h}$ incubation with increasing amounts of $\mathrm{BA}$ at $25^{\circ} \mathrm{C}$, to reach a maximal 70 fold induction with $64 \mathrm{mM}$ BA (SA $35.2 \pm 4.6 \mathrm{nmol} \mathrm{MU} / \mathrm{min} \mathrm{mg}$ ) (Figure 6A). At this concentration, the $\mathrm{Fv} / \mathrm{Fm}$ ratio was decreased by $8 \%$, but was fully recovered $16 \mathrm{~h}$ post-induction. Higher BA concentrations caused a severe

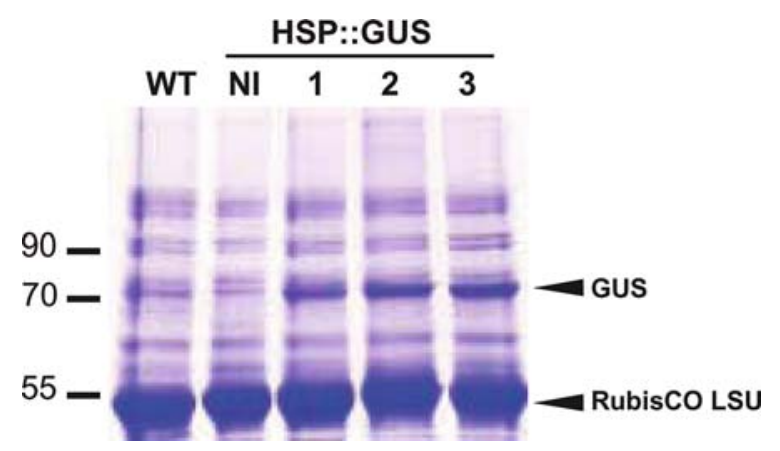

Figure 5. Coomassie blue detectable amounts of GUS after repetitive heat-induction. $50 \mu \mathrm{g}$ of total proteins prepared from WT or HSP::GUS protonema were separated by $8 \%$ SDS-PAGE and stained with Coomassie brilliant blue R250. (WT) Protein extract from wild type after $1 \mathrm{~h}$ heat treatment at $38^{\circ} \mathrm{C}$ and $4 \mathrm{~h}$ recovery at $25^{\circ} \mathrm{C}$. (NI) Protein extract from untreated HSP::GUS protonema (SA $=0.54 \mathrm{nmol} \mathrm{MU} / \mathrm{min}$ $\mathrm{mg}$ ). Protein extract from HSP::GUS protonema after the first induction cycle $(\mathrm{SA}=697.35 \mathrm{nmol} \mathrm{MU} / \mathrm{min} \mathrm{mg}$ ) (1), after the second induction cycle $(\mathrm{SA}=1264 \mathrm{nmol} \mathrm{MU} / \mathrm{min}$ $\mathrm{mg})(2)$ and after the third induction cycle $(\mathrm{SA}=1709 \mathrm{nmol}$ $\mathrm{MU} / \mathrm{min} \mathrm{mg}$ ) (3). One cycle $=1 \mathrm{~h}$ at $38{ }^{\circ} \mathrm{C}$ and $4 \mathrm{~h}$ recovery at $25^{\circ} \mathrm{C}$. The arrowheads indicate the position of GUS protein and RubisCO LSU. decrease and only a partial recovery of $\mathrm{Fv} / \mathrm{Fm}$ (Figure 6C).

Also significant, was the effect of acetyl salicylic acid ASA, a non-steroid anti-inflammatory drug affecting heat-shock signalling in animals (Amici et al., 1995). When protonemata from the HSP::GUS line were treated (at $25^{\circ} \mathrm{C}$ ) for $1 \mathrm{~h}$ with increasing ASA concentrations, a significant dosedependent induction of the GUS activity was observed. A maximum induction of 125 -fold was reached at $0.9 \mathrm{mM}$ ASA (SA $100 \pm 12 \mathrm{nmol} \mathrm{MU} /$ min $\mathrm{mg}$ ). This maximal GUS expression was 8 -fold lower than optimal heat-induction, but 1.5 -fold higher than Ubi-1-mediated expression (Figure 6B). As with heat-treatment, constant GUS activity was observed in the UBI:: GUS line when treated with increasing concentrations of ASA (Figure 6B). Measurements of chlorophyll $a$ fluorescence confirmed that ASA concentrations above $0.3 \mathrm{mM}$ reduced, albeit reversibly, the photochemical efficiency of PSII (Figure 6D). Exposures for more than $1 \mathrm{~h}$ to $0.8 \mathrm{mM}$ ASA resulted in a lower GUS expression, likely because of irreversible damages (data not shown).

Acetyl salicylic acid induction was confirmed with the HSP::GT strain. Whereas $1 \mathrm{~h}$ exposure at $38{ }^{\circ} \mathrm{C}$ resulted in a uniform GFP-talin labelling of a majority of $P$. patens cells, treatment with $0.8 \mathrm{mM}$ ASA resulted in a strong labelling but only in the youngest apical and sub-apical cells. Thus, unlike heat-induction, reporter protein expression in differentiated old cells was poorly inducible by ASA treatment (Figure 4J). Similar results were observed with histochemical staining of ASA-treated HSP::GUS protonema (data not shown). This effect is possibly due to the physical barriers, such as thicker cell walls in older tissues that limit the accessibility of ASA and BA. Despite the non-homogenous expression, actin filaments were clearly observed in ASA-induced young cells and were indistinguishable from those in heattreated young cells (data not shown).

\section{Discussion}

Here, we describe a highly efficient inducible protein-expression system in the moss $P$. patens, using a highly sensitive heat-inducible promoter from soybean. A detailed analysis of regulatory elements in the $h s p 17.3 B$ promoter identifies 

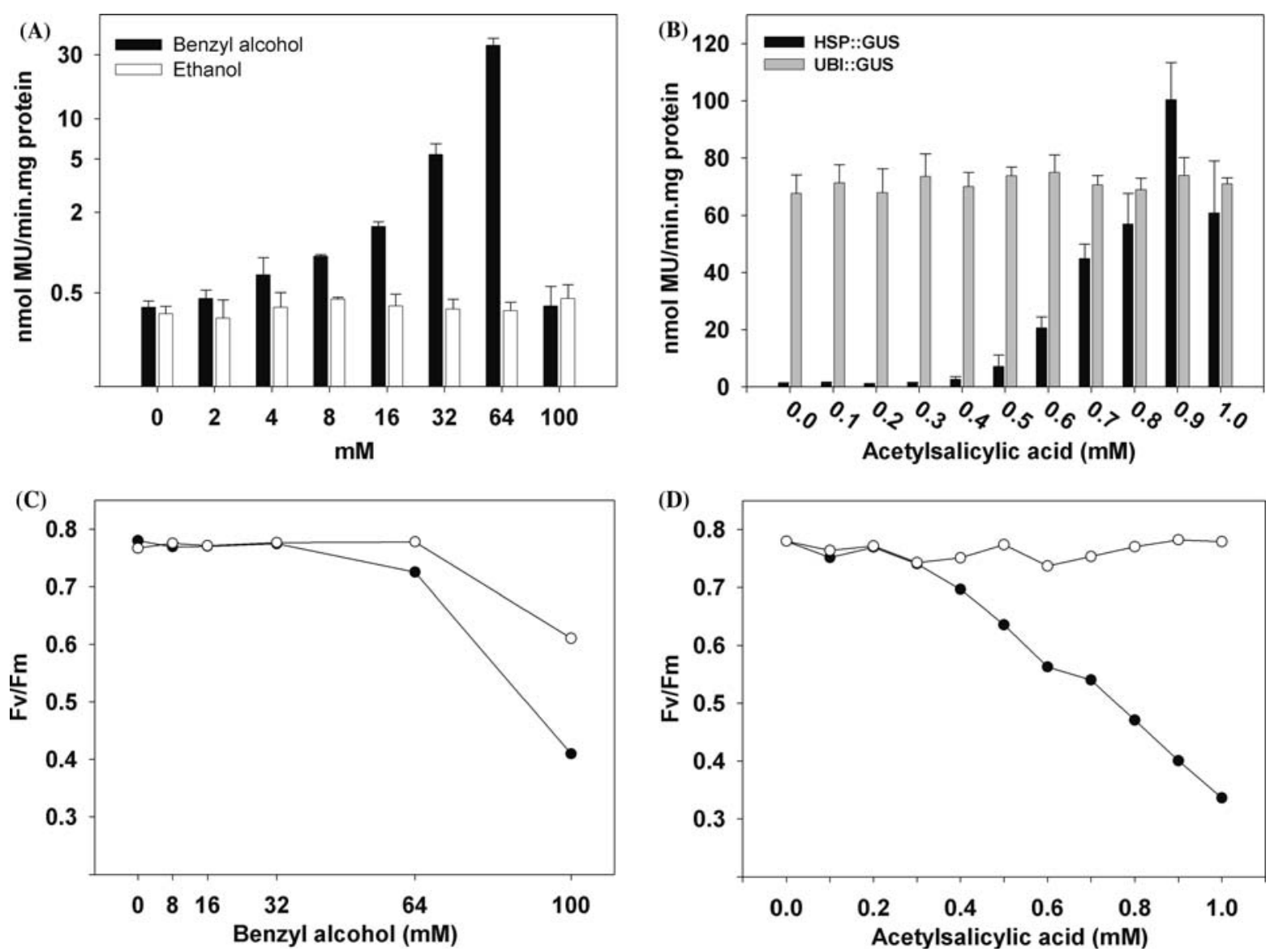

Figure 6. Chemical induction of GUS expression at $25{ }^{\circ} \mathrm{C}$. (A) GUS expression levels induced by benzyl alcohol (BA) treatment. Protonemata of the HSP::GUS line were incubated in a minimal medium supplemented with different concentrations of benzyl alcohol. As a control, protonemata were also incubated in a medium supplemented with equivalent concentrations of ethanol. (B) GUS induction levels after $1 \mathrm{~h}$ acetyl salicylic acid (ASA) treatment at different concentrations. Protonemata of the HSP::GUS or the UBI::GUS strain were transferred to a minimal medium supplemented with ASA for $1 \mathrm{~h}$ at $25^{\circ} \mathrm{C}$. GUS activities were measured $16 \mathrm{~h}$ after each chemical treatment and are expressed as nmol MU/min mg. (C, D) Changes in the maximum efficiency of PSII photochemistry (Fv/Fm) after treatment with BA (C) or ASA (D). Measures of PSII activity were determined immediately after the chemical treatment $(\bigcirc)$ and after $16 \mathrm{~h}$ recovery at $25{ }^{\circ} \mathrm{C}(\mathrm{O})$.

several heat shock regulating elements located between -321 and $-12 \mathrm{bp}$ and an additional enhancer element located between -593 and -312 bp (Rieping and Schoffl, 1992). The promoter we used covers the $5^{\prime}$ UTS of the $h s p 17.3 B$ promoter from -512 to -5 , containing the enhancer element. The data presented demonstrate that the molecular mechanism of the heat-shock response is highly conserved between bryophytes and spermatophytes. For promoters of sHSPs, optimal induction temperatures, dose-dependent responses and kinetics of protein expression were similar in $P$. patens, $A$. thaliana and Tomato (Baniwal et al., 2004) (for a review see (Nover et al., 2001)). In Table 1, the reporter activities driven by the soybean $h s p 17.3 B$ promoter were compared to that driven by other constitutive and inducible promoters tested in $P$. patens. Under non-inducing condition, hsp 17.3B-mediated GUS expression was extremely low: about 6-8-fold lower than that observed with a $35 \mathrm{~S}-\mathrm{GUS}$ construct carrying an optimised translation initiation context (pNcoGUS), 50-fold lower than that driven by the rice actin- 1 (act-1) promoter and at least 100 -fold lower than that driven by the maize Ubi-1 promoter. Using a dual luciferase assay, a comparison of the relative strength of the $35 \mathrm{~S}$ and act-1 promoters in moss provided similar values 
Table 1. GUS or Luciferase activities with constitutive and inducible promoters in P. patens.

\begin{tabular}{|c|c|c|c|c|c|c|}
\hline & Plasmid (a) & Test (b) & & $\begin{array}{l}\text { GUS } \\
\text { (c) }\end{array}$ & $\begin{array}{l}\text { GUS } \\
\text { normalised (d) }\end{array}$ & $\begin{array}{l}\text { Luciferase normalised } \\
\text { values }\end{array}$ \\
\hline \multicolumn{7}{|c|}{ Constitutive promoters } \\
\hline \multirow[t]{3}{*}{ CaMV 35S } & pNcoGUS (1) & $\mathrm{T}$ & & 3 & 1.0 & \\
\hline & pNcoGUS (2) & $\mathrm{S}$ & & 3 & 1.0 & \\
\hline & 35S-LUC (3) & $\mathrm{T} / \mathrm{DF}$ & & & & 1 \\
\hline \multirow[t]{2}{*}{ Rice $a c t 1$} & Act1-F (1) & $\mathrm{T}$ & & 25 & 8.3 & \\
\hline & (3) & $\mathrm{T} / \mathrm{DF}$ & & & & $10 \pm 5.5$ \\
\hline \multirow[t]{3}{*}{ Maize Ubi-1 } & Ubi-GUS (4) & $\mathrm{T}$ & & 50 & 16.7 & \\
\hline & pUBI-GUS-MU108H ${ }^{*}$ & $\mathrm{~S}$ & & 70 & 23.3 & \\
\hline & Plasmid (a) & Test (b) & Treatment (f) & GUS (c) & $\begin{array}{l}\text { GUS } \\
\text { normalised (d) }\end{array}$ & $\begin{array}{l}\text { Induction } \\
\text { factor (e) }\end{array}$ \\
\hline \multirow[t]{3}{*}{$\begin{array}{l}\text { Inducible promoters } \\
\text { wheat } E m\end{array}$} & BM $113(5)$ & $\mathrm{S}$ & $\mathrm{H}_{2} \mathrm{O}$ & 20 & 6.7 & 1 \\
\hline & & & Mannitol & 93 & 31.0 & 6 \\
\hline & & & $\mathrm{ABA}$ & 550 & 183.3 & 30 \\
\hline \multirow{2}{*}{$\begin{array}{l}\text { Glucocorticoid } \\
\text { inducible }\end{array}$} & Act-GVG + UAS GUS (1) & $\mathrm{T}$ & - Dex & 2 & 0.7 & 1 \\
\hline & & & + Dex & 35 & 11.7 & 15 \\
\hline \multirow[t]{2}{*}{ Ethanol inducible } & 35S AlcR + Alc-GUS (4) & $\mathrm{T}$ & $-\mathrm{EtOH}$ & 12 & 4.0 & 1 \\
\hline & & & $+\mathrm{EtOH}$ & 14 & 4.7 & 1.2 \\
\hline \multirow{6}{*}{$\begin{array}{l}\text { Tetracycline } \\
\text { repressible } \\
\text { hsp } 17.3 B\end{array}$} & ptTA + pTop10 (2) & $\mathrm{T} / \mathrm{S}$ & $+\mathrm{Tc}$ & $>0.05$ & 0.02 & 1 \\
\hline & & & $-\mathrm{Tc}$ & 4 & 1.3 & 65 \\
\hline & pHSP-GUS-AH108* & $\mathrm{S}$ & $25{ }^{\circ} \mathrm{C}$ & 0.5 & 0.16 & 1 \\
\hline & & & $38^{\circ} \mathrm{C}$ & 850 & 283 & 1500 \\
\hline & & & ASA & 100 & 33 & 125 \\
\hline & & & BA & 35 & 12 & 70 \\
\hline
\end{tabular}

Notes: (a) References for theses values are (1) (Chakhparonian, 2001), (2) (Zeidler et al., 1996; Zeidler et al., 1999), (3) (Horstmann et al., 2004), (4) Schaefer and Finka, unpublished data, (5) (Knight et al., 1995), * this work. (b) T transient gene expression, S stable transgenic lines, DF dual luciferase assay. (c) GUS specific activities are given in $\mathrm{nmol} \mathrm{MU} / \mathrm{min} \mathrm{mg}$ protein. The values obtained in reference (1) were averaged from at least 6 independent transformations and standard deviations between transformations never exceeded $25 \%$. (d) GUS activities were normalised to the value of the $35 \mathrm{~S}$ promoter, to enable comparison with the dual luciferase assay. (e) Determined relatively to the non-induced GUS level obtained with the same system. (f) ABA: abscisic acid, Dex: dexamethasone, Et OH: ethanol, Tc: tetracycline, BA: benzyl alcohol, ASA: acetyl salicylic acid.

(Horstmann et al., 2004). Finally, this low basal level was about 4-6-fold lower than the basal level measured in $P$. patens for the glucocorticoidinducible GVG system (Chakhparonian, 2001). The $h s p 17.3 B$ expression system in the moss thus satisfies the quality requirement for minimal promoter leakiness.

A tight dose-response relationship was established between the level of induced gene-expression and the temperature (Figure 1) and/or duration (Figure 2) of the heat induction. Gene expression was induced accurately over three orders of magnitude and maximal induction was achieved following one hour at $38{ }^{\circ} \mathrm{C}$. This condition was not associated with apparent heat damages and maximal GUS activity corresponded to about $1 \%$ GUS protein of TSP. This activity is at least 10fold higher than that driven by the strong maize
Ubi-1 promoter. Kinetic experiments showed that maximal induction was rapidly achieved (within $1 \mathrm{~h}$ ), transient and lasted up to $8 \mathrm{~h}$ post-induction. The hsp $17.3 B$ promoter thus enables the finetuning of transient gene expression in moss, which satisfies the requirement for a reproducible, dosedependent, inducible gene-expression system.

Noticeably, a low activity of the hsp $17.3 B$ promoter has been reported in developing tobacco seeds without heat shock (Prandl et al., 1995). In contrast, histochemical and in vivo labelling showed that the $h s p 17.3 B$ promoter had no tissue-specific pattern of expression in $P$. patens. Heat-induced GUS was uniformly expressed in most cells of the plant. By contrast, in UBI::GUS line, GUS molecules accumulated more in aging cells than in younger cells. In HSP::GT line, a uniform labelling of actin structures was also 
observed in vivo (Figure 4). This allowed for the first time to clearly visualize different actin structures at all stages of cellular differentiation in various tissues. Interestingly, transgenic A. thaliana constitutively expressing $35 \mathrm{~S}$-mediated GFP-talin displayed labelled actin filaments only in developed trichomes, some leaf cells and root hairs (Mathur et al., 1999). Moreover, constitutive over-expression of GFP-talin in pollen tubes inhibited pollen germination (Kost et al., 1998). Thus, by controlling the precise timing of expression and the cellular concentrations of recombinant proteins, an $h s p 17.3 B$-based conditional expression system may circumvent dominant-negative effects, such as cell growth inhibition by excess GFP-talin. We conclude that the $h s p 17.3 B$ promoter fulfils all the methodological criteria for a most reliable, non-leaky, controllable, inducible gene-expression system in $P$. patens. The other inducible gene-expression systems developed for plants and tested in P. patens do not fully satisfy such criteria. Many of them have significantly leakier promoters, drive lower induction levels and/or necessitate the use of toxic chemical inducers (see Table 1).

\section{Chemical induction of the heat shock promoter}

In plants, little is known about chemicals that can specifically induce the heat-shock response. We have shown here that BA, affecting membrane fluidity in E. coli and cyanobacteria (Vigh et al., 1998), or ASA, affecting the activity of heat shock factors in mammals (Amici et al., 1995), can induce $h s p 17.3 B$-mediated GUS expression at room temperature (Figure 6). In both cases, induction factors were proportional to the concentration of the chemicals and maximal induction was at comparable concentrations as observed in cyanobacteria with BA and in mammalian cells with ASA. Yet, maximal GUS activities were respectively, 8 and 25 -folds lower for ASA and BA, than with optimal heat-induction. This is because of the uneven expression pattern that we observed using HSP::GT line (Figure 4H/4J). Permeability differences in the cell walls of young and old cells may determine the accessibility and efficacy of chemical inducers, especially hydrophobic ones. Yet, this is the first report of BA and ASA-induced activation of a heat-shock promoter in plants. Chemical induction of the $h s p 17.3 B$ promoter provides an alternative to heat-induction, when heat-treatments are to be avoided, as in the case of expressing a heat-sensitive protein.

\section{Biotechnological applications}

Technical advances and limitations of plant-based protein production systems have been recently detailed in (Fischer et al., 2004). We showed here a high yield $(2.3 \%$ TSP) obtained with a cytosolic protein-expression system. This yield corresponds to $3.5 \mathrm{mg}$ GUS produced per gram dry weight and is two orders of magnitude higher than that obtained for a recombinant human growth factor expressed in P. patens (10-13 $\mu \mathrm{g} / \mathrm{g}$ dry weight (Jost et al., 2005)). P. patens suspension culture can be grown in fermentors (Decker and Reski, 2004) and can therefore be used for the industrial production of recombinant proteins. In addition, secretion signals are highly conserved between moss and other eukaryotes and can thus be used to target produced proteins to various cellular compartments and to the secretory pathway for collection in the extracellular medium (Decker and Reski, 2004). The major advantage of $P$. patens is its exceptional amenability to targeted gene-mutagenesis. This allows inactivation of specific functions, such as proteases that may degrade recombinant proteins, or enzymes involved in immunogenic post-translational glycosylations (Koprivova et al., 2004). Finally, the high rate at which high amounts of $h s p 17.3 B$-mediated recombinant proteins can accumulate in moss $(2.3 \%$ of TSP in half a day) is of significant biotechnological interest. Higher yields have been reported using a chloroplast transgenic system in tobacco $(31.1 \%$ TSP $)$ (Molina et al., 2004) and a seed specific promoter in $A$. thaliana (36.5\% TSP) (De Jaeger et al., 2002). However, the time required to achieve such amounts was 60 and at least 40 days, respectively.

In conclusion, our findings have three major applications. (1) The versatility of the system enables the fine-tuning of transient gene expression over three orders of magnitude in all cells and tissues, in a dose dependent manner, with very low promoter leakiness. This would enable correlation studies between expression levels and biological function of given proteins. (2) The behaviour of this promoter in response to non-damaging heat treatment in $P$. patens is identical to that 
previously described in tobacco and A. thaliana. Thus, further functional studies of the plant heat-shock response can be advantageously complemented in $P$. patens. (3) The yield of protein production and the rate of protein accumulation in the moss after iterative heat induction cycles is remarkably high. This can serve as efficient biotechnological tool for controlled production of industrial recombinant proteins.

\section{Acknowledgements}

This research was funded by grant 31-65211.01 from the Swiss National Science Foundation. Authors thank E. Lam, M. Lawton, M. Uzé and R. Strasser for plasmids and comments.

\section{References}

Ainley, W.M. and Key, J.L. 1990. Development of a heat shock inducible expression cassette for plants: characterization of parameters for its use in transient expression assays. Plant Mol. Biol. 14: 949-967.

Amici, C., Rossi, A. and Santoro, M.G. 1995. Aspirin enhances thermotolerance in human erythroleukemic cells: an effect associated with the modulation of the heat shock response. Cancer Res 55: 4452-4457.

Aoyama, T. and Chua, N.-H. 1997. A glucocorticoid-mediated transcriptional induction system in transgenic plants. Plant J. 11: 605-611.

Ashton, N.W., Grimsley, N.H. and Cove, D.J. 1979. Analysis of gametophytic development in the moss Physcomitrella patens, using auxin and cytokinin resistant mutants. Planta 144: $427-435$.

Baniwal, S.K., Bharti, K., Chan, K.Y., Fauth, M., Ganguli, A., Kotak, S., Mishra, S.K., Nover, L., Port, M., Scharf, K.D., Tripp, J., Weber, C., Zielinski, D. and von Koskull-Doring, P. 2004. Heat stress response in plants: a complex game with chaperones and more than twenty heat stress transcription factors. J. Biosci. 29: 471-87.

Bierfreund, N.M., Reski, R. and Decker, E.L. 2003. Use of an inducible reporter gene system for the analysis of auxin distribution in the moss Physcomitrella patens. Plant Cell Rep. 12: 1143-1152.

Bonneville, J.M., Sanfaçon, H., Fütterer, J. and Hohn, T. 1989. Posttranscriptionnal trans-activation in Cauliflower Mosaic Virus. Cell 59: 1135-1143.

Caddick, M.X., Greenland, A.J., Jepson, I., Krause, K.P., Qu, N., Riddel, K.V., Salter, M.G., Schuch, W., Sonnewald, U. and Tomsett, A.B. 1998. An ethanol inducible gene switch for plants used to manipulate carbon metabolism. Nature Biotechnol. 16: 177-180.

Chakhparonian, M. 2001. Développement d'outils de la mutagenèse ciblée par recombinaison homologue chez
Physcomitrella patens. Université de Lausanne, Switzerland "www.unil.ch/lpc/docs/".

Cove, D.J., Knight, C.D. and Lamparter, T. 1997. Mosses as model systems. Trends in Plant Sci. 2: 99-105.

De Jaeger, G., Scheffer, S., Jacobs, A., Zambre, M., Zobell, O., Goossens, A., Depicker, A. and Angenon, G. 2002. Boosting heterologous protein production in transgenic dicotyledonous seeds using Phaseolus vulgaris regulatory sequences. Nature Biotechnol. 20: 1265-1268.

Decker, E.L. and Reski, R. 2004. The moss bioreactor. Curr. Opin. Plant Biol. 7: 166-70.

Diamant, S., Ben-Zvi, A.P., Bukau, B. and Goloubinoff, P. 2000. Size-dependent disaggregation of stable protein aggregates by the DnaK chaperone machinery. J. Biol. Chem. 275: 21107-21113.

Donovan, R.S., Robinson, C.W. and Glick, B.R. 1996. Optimizing inducer and culture conditions for expression of foreign proteins under the control of the lac promoter. $\mathbf{J}$. Ind. Microbiol. 16: 145-154.

Doonan, J.H. and Duckett, J.D. 1988. The bryophyte cytoskeleton: experimental and immunofluorescence studies of morphogenesis. Adv. Bryol. 3: 1-31.

Fischer, R., Stoger, E., Schillberg, S., Christou, P. and Twyman, R.M. 2004. Plant-based production of biopharmaceuticals. Curr. Opin. Plant Biol. 7: 152-158.

Gatz, C. 1997. Chemical control of gene expression. Ann. Rev. Plant Physiol. Plant Mol. Biol. 48: 89-108.

Havaux, M. 1992. Stress tolerance of photosystem II in vivo. Plant Physiol. 100: 424-432.

Horstmann, V., Huether, C.M., Jost, W., Reski, R. and Decker, E.L. 2004. Quantitative promoter analysis in Physcomitrella patens: a set of plant vectors activating gene expression within three orders of magnitude. BMC Biotechnol. 4: 1-13.

Jefferson, R.A., Kavanagh, T.A. and Bevan, M.W. 1987. GUS fusions: $\beta$-glucuronidase as a sensitive and versatile gene fusion marker in higher plants. EMBO J. 6: 3901-3907.

Johnston, M. 1987. A model fungal gene regulatory mechanism: the GAL genes of Saccharomyces cerevisiae. Microbiol. Rev. 51: 458-476.

Jost, W., Link, S., Horstmann, V., Decker, E.L., Reski, R. and Gorr, G. 2005. Isolation and characterisation of three mossderived beta-tubulin promoters suitable for recombinant expression. Curr. Genet. 47: 111-120.

Jurivich, D.A., Sistonen, L., Kroes, R.A. and Morimoto, R.I. 1992. Effect of sodium salicylate on the human heat shock response. Science 255: 1243-1245.

Kilby, N.J., Fyvie, M.J., Sessions, R.A., Davies, G.J. and Murray, J.A. 2000. Controlled induction of GUS marked clonal sectors in Arabidopsis. J. Exp. Bot. 51: 853-863.

Knight, C.D., Sehgal, A., Atwal, K., Wallace, J.C., Cove, D.J., Coates, D., Quatrano, R.S., Bahadur, S., Stockley, P.G. and Cuming, A.C. 1995. Molecular responses to abscisic acid and stress are conserved between moss and cereals. Plant Cell 7: 499-506.

Koprivova, A., Stemmer, C., Altmann, F., Hoffmann, A., Kopriva, S., Gorr, G., Reski, R. and Decker, E.L. 2004. Targeted knockouts of Physcomitrella lacking plant-specific immunogenic N-glycans. Plant Biotechnol. J. 2: 517-523.

Kost, B., Spielhofer, P. and Chua, N.H. 1998. A GFP-mouse talin fusion protein labels plant actin filaments in vivo and visualises the actin cytoskeleton in growing pollen tubes. Plant J. 16: 393-401.

Krueger, G.H.J., Tsimilli-Michael, M. and Strasser, R.J. 1997. Light stress provokes plastic and elastic modifications in 
structure and function of photosystem II in camellia leaves. Physiol. Plantarum 101: 256-277.

Lu, C., Qiu, N., Wang, B. and Zhang, J. 2003. Salinity treatment shows no effects on photosystem II photochemistry, but increases the resistance of photosystem II to heat stress in halophyte Suaeda salsa. J. Exp. Bot. 54: 851-860.

Lyznik, L.A., Hirayama, L., Rao, K.V., Abad, A. and Hodges, T.K. 1995. Heat-inducible expression of FLP gene in maize cells. Plant J. 8: 177-186.

Masclaux, F., Charpenteau, M., Takahashi, T., Pont-Lezica, R. and Galaud, J.P. 2004. Gene silencing using a heat-inducible RNAi system in Arabidopsis. Biochem. Biophys. Res. Commun. 321: 364-369.

Mathur, J., Spielhofer, P., Kost, B. and Chua, N. 1999. The actin cytoskeleton is required to elaborate and maintain spatial patterning during trichome cell morphogenesis in Arabidopsis thaliana. Development 126: 5559-5568.

Maundrell, K. 1993. Thiamine-repressible expression vectors pREP and pRIP for fission yeast. Gene 123: 127-130.

McElroy, D., Blowers, A.D., Jenes, B. and Wu, R. 1991. Construction of expression vectors based on the rice actin 1 (Act1) $5^{\prime}$ region for the use in monocot transformation. Mol. Gen. Genet. 231: 150-160.

Merquiol, E., Pneuli, L., Cohen, M., Simovitch, M., Rachmilevitch, S., Goloubinoff, P., Kaplan, A. and Mittler, R. 2002. Seasonal and diurnal variations in gene expression in the desert legume Retama raetam. Plant Cell Environ. 25: 1627-1638.

Molina, A., Hervas-Stubbs, S., Daniell, H., Mingo-Castel, A. M. and Veramendi, J. 2004. High-yield expression of a viral peptide animal vaccine in transgenic tobacco chloroplasts. Plant Biotechnol. J. 2: 141-153.

Nishal, B., Tantikanjana, T. and Sundaresan, V. 2005. An inducible targeted tagging system for localized saturation mutagenesis in Arabidopsis. Plant Physiol. 137: 3-12.

Nishiyama, T., Fujita, T., Shin, I.T., Seki, M., Nishide, H., Uchiyama, I., Kamiya, A., Carninci, P., Hayashizaki, Y., Shinozaki, K., Kohara, Y. and Hasebe, M. 2003. Comparative genomics of Physcomitrella patens gametophytic transcriptome and Arabidopsis thaliana: implication for land plant evolution. Proc. Natl. Acad. Sci. USA 100: 8007-8012.

Nishiyama, T., Hiwatashi, Y., Sakakibara, I., Kato, M. and Hasebe, M. 2000. Tagged mutagenesis and gene-trap in the moss, Physcomitrella patens by shuttle mutagenesis. DNA Res. 7: 9-17.

Nover, L., Bharti, K., Doring, P., Mishra, S.K., Ganguli, A. and Scharf, K.D. 2001. Arabidopsis and the heat stress transcription factor world: how many heat stress transcription factors do we need? Cell Stress Chaperones 6: 177-189.

Padidam, M. 2003. Chemically regulated gene expression in plants. Curr. Opin. Plant Biol. 6: 169-177.

Prandl, R., Kloske, E. and Schöffl, F. 1995. Developmental regulation and tissue-specific differences of heat shock gene expression in transgenic tobacco and Arabidopsis plants. Plant Mol. Biol. 28: 73-82.

Rensing, S.A., Rombauts, S., Van de Peer, Y. and Reski, R. 2002. Moss transcriptome and beyond. Trends Plant Sci. 7: 535-538.

Reski, R. 1998. Development, genetics and molecular biology of mosses. Bot. Acta 111: 1-15.

Rieping, M. and Schoffl, F. 1992. Synergistic effect of upstream sequences, CCAAT box elements, and HSE sequences for enhanced expression of chimaeric heat shock genes in transgenic tobacco. Mol. Gen. Genet. 231: 226-232.
Rizhsky, L., Liang, H.J., Shuman, J., Shulaev, V., Davletova, S. and Mittler, R. 2004. When desense pathways collide. The response of Arabidopsis to a combination of drought and heat stress. Plant Physiol. 134: 1683-1696.

Roslan, H.A., Salter, M.G., Wood, C.D., White, M.R., Croft, K.P., Robson, F., Coupland, G., Doonan, J., Laufs, P., Tomsett, A.B. and Caddick, M.X. 2001. Characterisation of an ethanol-inducible alc gene-expression system in Arabidopsis thaliana. Plant J. 28: 225-235.

Schaefer, D.G. 2002. A new moss genetics: targeted mutagenesis in Physcomitrella patens. Annu. Rev. Plant Biol. 53: 477-501.

Schaefer, D.G. and Zryd, J.P. 1997. Efficient gene targeting in the moss Physcomitrella patens. Plant J. 11: 1195-1206.

Schaefer, D.G. and Zryd, J.P. 2001. The moss Physcomitrella patens, now and then. Plant Physiol. 127: 1430-1438.

Schaefer, D.G. and Zryd, J.P. 2004. Principles of targeted mutagenesis in the moss Physcomitrella patens. In: A.J. Wood, M.J. Oliver and D. Cove (Eds.), New Frontiers in Bryology, Kluwer Academic Publishers, Dordrecht, Boston, London, pp. 37-49.

Schöffl, F., Raschke, E. and Nagao, R.T. 1984. The DNA sequence analysis of soybean heat-shock genes and identification of possible regulatory promoter elements. The EMBO J. 3: 2491-2497.

Schöffl, F., Rieping, M., Baumann, G., Bevan, M. and Angermuller, S. 1989. The function of plant heat shock promoter elements in the regulated expression of chimaeric genes in transgenic tobacco. Mol. Gen. Genet. 217: 246-253.

Schweizer, P., Pokorny, J., Abderhalden, O. and Dudler, R. 1999. A transient assay system for the functional assessment of defense-related genes in wheat. Mol. Plant Microbe Interact. 12: 647-654.

Severin, K. and Schoffl, F. 1990. Heat-inducible hygromycin resistance in transgenic tobacco. Plant Mol. Biol. 15: 827-833.

Shigapova, N., Török, S., Balogh, G., Goloubinoff, P., Vigh, L. and Horvath, I. 2005. Membrane fluidization triggers membrane remodeling which affects the thermotolerance in Escherichia coli. Biochem. Biophys. Res. Commun. 328: 1216-1223.

Srivastava, A., Guissé, B., Greppin, H. and Strasser, R.J. 1997. Regulation of antenna structure and electron transport in photosystem II of Pisum sativum under elevated temperature probed by the fast polyphasic chlorophyll $a$ fluorescence transient:OKJIP. Biochemica et Biophysica acta 1320:95-106.

Strasser, R.J., Srivastava, A. and Govindjee, 1995. Polyphasic chlorophyll $a$ fluorescence transient in plants and cyanobacteria. Phytochem. photobiol. 61: 32-42.

Sun, W., Van Montagu, M. and Verbruggen, N. 2002. Small heat shock proteins and stress tolerance in plants. Biochim. Biophys. Acta 1577: 1-9.

Vierling, E. and Kimpel, J.A. 1992. Plant responses to environmental stress. Curr. Opin. Biotechnol. 3: 164-170.

Vigh, L., Maresca, B. and Harwood, J.L. 1998. Does the membrane's physical state control the expression of heat shock and other genes? Trends Biochem. Sci. 23: 369-374.

Yoshida, K., Kasai, T., Garcia, M.R., Sawada, S., Shoji, T., Shimizu, S., Yamazaki, K., Komeda, Y. and Shinmyo, A. 1995. Heat-inducible expression system for a foreign gene in cultured tobacco cells using the HSP18.2 promoter of Arabidopsis thaliana. Appl. Microbiol. Biotechnol. 44: 466-472.

Zeidler, M., Gatz, C., Hartmann, E. and Hughes, J. 1996. Tetracycline-regulated reporter gene expression in the moss Physcomitrella patens. Plant Mol. Biol. 30: 199-205. 
Zeidler, M., Hartmann, E. and Hughes, J. 1999. Transgene expression in the moss Ceratodon purpureus. J. Plant Physiol. 154: $641-650$.
Zuo, J., Niu, Q.-W. and Chua, N.-H. 2000. An estrogen receptor-based transactivator XVE mediates highly inducible gene expression in transgenic plants. Plant J. 24: 265-273. 